\title{
Politics as Religion
}





\title{
Politics as Religion
}

\author{
Emilio Gentile
}

Translated by George Staunton

P R I N C E T O N U N I V E R S I T Y P R E S S

P R I N C E T O N A N D O X F O R D 
First published in Italian under the title Le religioni della politica:

Fra democrazie e totalitarismi

(c) 2001, Gius. Laterza \& Figli. This translation of

Le religioni della politica is published by arrangement with Gius. Laterza \& Figli S.P.A., Roma-Bari.

English translation Copyright (C2006 by Princeton University Press

Published by Princeton University Press, 41 William Street,

$$
\text { Princeton, NJ } 08540
$$

In the United Kingdom: Princeton University Press,

3 Market Place, Woodstock, Oxfordshire 0X20 1SY

All Rights Reserved

Library of Congress Cataloging-in-Publication Data

Gentile, Emilio, 1946-

[Religioni della politica. English]

Politics as religion / Emilio Gentile; translated

by George Staunton.

p. cm.

Includes bibliographical references.

ISBN-13: 978-0-691-11393-7 (cloth : alk. paper)

ISBN-10: 0-691-11393-9 (cloth : alk. paper)

1. Ideology-Political aspects. 2. Religion and politics.

3. Political psychology. I. Title.

HM641.G4613 2006

306.2-dc22 2005044498

British Library Cataloging-in-Publication Data is available

This book has been composed in Sabon

Printed on acid-free paper. $\infty$

pup.princeton.edu

Printed in the United States of America

$\begin{array}{llllllllll}1 & 3 & 5 & 7 & 9 & 10 & 8 & 6 & 4 & 2\end{array}$ 
At different periods dogmatic belief is more or less common. It arises in different ways, and it may change its object and its form; but under no circumstances will dogmatic belief cease to exist, or, in other words, men will never cease to entertain some opinions on trust and without discussion. If everyone undertook to form all his own opinions and to seek for truth by isolated paths struck out by himself alone, it would follow that no considerable number of men would ever unite in any common belief.

But obviously without such common belief no society can prosper; say, rather, no society can exist; for without ideas held in common there is no common action, and without common action there may still be men, but no social body. In order that society should exist and, a fortiori, that a society should prosper, it is necessary that the minds of all the citizens should be rallied and held together by certain predominant ideas; and this cannot be the case unless each of them sometimes draws his opinions from the common source and consents to accept certain matters of belief already formed.

-Alexis de Tocqueville, Democracy in America, vol. 2 , chapter 2

It makes you wonder whether the modern world, which studies and reads, and therefore should be emancipated from myth and many natural terrors, really is, when taken as a whole, freer from prejudices, and does not give into much more dangerous prejudices.

-Jacob Burckhardt, Griechische Kulturgeschichte

But there is no need of gods nor secret conspiracies to drive men towards the most absurd catastrophes. Human nature alone is quite sufficient.

- Simone Weil, Let's Not Fight the Trojan War Again 
